\title{
PREGNANCY - THE STATE OF CHANGES IN THE FIELD OF MOTIVATION ASPECTS FOR SPORT EXERCISING TOO
}

\author{
Podlesnik Fetih Anja ${ }^{1}$ \\ ${ }^{1}$ Primary School Rakek, Domžale, Slovenia
}

\begin{tabular}{llr} 
DOI: $10.5550 /$ sgia.1002045 & COBISS.BH-ID 1846040 & SHORT SCIENTIFIC ARTICLE \\
UDC: $618.3: 796.012 .1: 331.101 .3$ \\
\hline
\end{tabular}

\section{SUMMARY}

The article presents the results of the survey among 163 pregnant women before pregnancy, at the end of the first triad, and at the end of the second triad of pregnancy. The survey questions encompass the field of motivation for sport activity. The questionnaire consists of 23 statements concerning the motivation before and 25 statements concerning motivation during pregnancy. Individuals define their own motive for sport activity on the five-degree scale. We analyzed the repetition frequencies of all the motives in all three stages of pregnancy and established the crucial motives for engaging in sport activities before and during pregnancy. Motivational structures are relatively permanent structures of cognitive-conative area which begin to form in the early childhood; therefore we expect these chosen motives to appear in all stages. We ascertained that pregnant women should be as much as possible acquainted with the influence and significance of sport activity on their own and their child's health and wellbeing since these are the leading motives in all three stages of our measuring. Motives within motivational structure may change in specific circumstances. This is established by our findings as well as during pregnancy the motives of health of unborn child and positive influence of mother's wellbeing on child take high frequencies of occurrence.

Key words: motivational structure, sports activities, pregnancy.

\section{THE SUBJECT AND THE PROBLEM}

Exercising beneficially affects health of pregnant women and developing fetus and at the same time it is also a good preparation for a birth. Exercising also helps overcome some of pregnancy problems like constipation, tiredness, morning sickness and vomiting, more frequent urination, sleepiness and pains in the lower part of the stomach. Exercising by recommendations of many research findings (Brown, 2002; Lochmuller \& Friese, 2004) relaxes and beneficially influences psychological state of health, strengthens cardiovascular system, it is a good preparation of pelvic floor muscles for delivery, it gains less fat weight during pregnancy and relieves backaches and pains in other joints. Special exercises for pel- vic floor muscles not only help to strengthen muscles during pregnancy but also influence on shorter second pregnancy period because then a pregnant woman is more aware of the function of mentioned muscles and is able to relax them at the right time. In that way she can take an active part in delivery process which can now be faster and easier (Gamberger \& Videmšek, 2005).

Women, who exercised regularly before becoming pregnant, can continue their program even throughout pregnancy if it goes on normally. Many studies have shown (Pivarnik et al., 1993; Wolfe et al., 1999) that from early second trimester of pregnancy exercises should be of moderate-intensity to mediumintensity aerobic activity where heart beat does not exceed 140 beats per minute and it is recommended to perform them three to four 
times in a week in duration of $25-60$ minutes. With such an extent of exercise the loss of aerobic power is minimal and they'll gain less fat because of constant ongoing fat use (Clapp \& Little, 1995).

The aim of an active pregnant woman is to achieve many-sided positive affects. Benefits of regular exercising during pregnancy are: full muscular system strengthens which helps a pregnant woman to put up with additional strains easier throughout pregnancy and delivery; pregnant women learn how to control muscles - in this way during the process of delivery only specific groups of muscles are activated which is important for economical use of oxygen; muscles become more elastic so that women can regain their pre-pregnancy body back more quickly; the blood circulation increases which prevents varicosity and the baby gets more oxygen needed for his wellbeing and healthy development; the whole organism strengthens and gets ready for the events during delivery which can so be shorter and easier; physical and psychic condition improves and working ability maintains until high pregnancy; the feeling of safety during exercising maintains and accelerate the pleasure of exercising; a positive attitude toward pregnancy is developed and with that related mental well-being and serenity, it also prevents depression (Klun, 1992).

Goals of exercising that a certain pregnant woman has, differs from her pre-pregnancy goals. Exercising itself is more than just toning muscles and developing motor abilities, it is about keeping acquired abilities and getting even more focused on performance of movement. Throughout pregnancy exercising is more relaxed with lower intensity. Pregnant women should not gasp for breath during exercising and not at all get exhausted. Throughout pregnancy they should not start new sports or should avoid exercises with higher risk of injuries by using different requisites or risk of falling (Brown, 2002). They should work out in extent and with intensity that provides relaxation and well-being.

So, which are the motives that are essential for exercising in pre-pregnancy and throughout pregnancy? When we talk about motivational currents, we think about those in which an individual regardless to the awareness, regardless to theoretical knowledge, sees a vital benefit.

The level of individual's adaptation to living conditions depends on the level of effectiveness of motivational currents. Predomination of one or more motives over the others is a consequence of many different life situations and individual experience (Černohorski, 2001). Pregnancy as a condition full of physiological and psychological changes influences also on changes of motives that an individual pregnant woman has.

Many different ways of finding out motives are known, many of them can be quite complicated (they move on a base of establishing a latent space), and the others are very simple. In our case the most common and interesting reasons and answers were found for the needs of this study and were offered to women as a questionnaire. In one of the most important studies concerning motives or reasons for exercising in Slovenia on representative pattern of adults, following main motives for exercising appeared: good health and wellbeing, good physical and working abilities, having fun, amusement, relaxation, and pleasure in exercising, competition, physical effort, sports appearance and a friend's life style (Završnik, Pišot, Zurc, Žerjal, 2004). We have adjusted the assortment of motives to specialities throughout pregnancy.

\section{RESULTS AND DISCUSSION}

Our findings show that pregnancy as a state full of physiological and psychological changes has an influence on changes of motives of an individual woman. Following motives appeared with the highest frequency in pre-pregnancy: I want to be physically efficient, I want to keep my health, I want to improve my health and I want to be a good example for my children. Motives, less important are: competition, business reasons and sympathy towards trainers.

From the moment when a woman realizes she's pregnant, everything is adapted to the growing creature inside of her, beside old motives new ones appear and they stay relatively stable throughout pregnancy. Even two new 
motives appear: the health of unborn baby and a positive influence of mother's well-being on her baby. The less important motives in pre- pregnancy have even throughout pregnancy the lowest frequency of appearance.

TABLE 1.

Changes of motivational structure for exercising throughout pregnancy

\begin{tabular}{|c|c|c|c|}
\hline Motives for exercising & 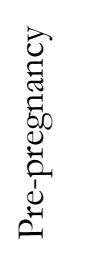 & 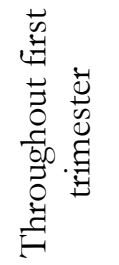 & 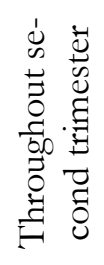 \\
\hline My well-being means a lot to me. & 4.61 & 4.63 & 4.69 \\
\hline I want to be with my friends. & 2.68 & 2.59 & 2.57 \\
\hline I want to release my energy. & 3.62 & 3.21 & 3.20 \\
\hline I want to stay in a good shape. & 4.09 & 4.12 & 4.09 \\
\hline I enjoy group workout. & 2.52 & 2.26 & 2.37 \\
\hline I want to learn new skills. & 2.64 & 2.31 & 2.27 \\
\hline I want to meet new friends. & 2.69 & 2.57 & 2.55 \\
\hline I want to release tension. & 3.72 & 3.33 & 3.30 \\
\hline I like doing something. & 3.50 & 3.44 & 3.36 \\
\hline I like going out of my house. & 3.75 & 3.75 & 3.64 \\
\hline I like the competition. & 1.64 & 1.48 & 1.48 \\
\hline I like being in a group. & 2.27 & 2.16 & 2.13 \\
\hline I want to make a progress to a higher level. & 2.42 & 2.10 & 2.18 \\
\hline I want to be physically efficient. & 4.03 & 4.13 & 4.13 \\
\hline I want to stay healthy. & 4.56 & 4.42 & 4.36 \\
\hline I like my trainers. & 1.62 & 1.63 & 1.64 \\
\hline I like having fun. & 3.12 & 2.96 & 2.89 \\
\hline I want to keep aesthetic appearance of my body. & 3.70 & 3.63 & 3.58 \\
\hline I want to improve my health. & 4.21 & 4.05 & 4.12 \\
\hline I want to be in touch with a social life. & 2.69 & 2.53 & 2.55 \\
\hline When becoming older I want to be fit. & 3.93 & 3.75 & 3.71 \\
\hline I want to be a good example for my children. & 4.06 & 3.96 & 3.98 \\
\hline I am active for business reasons. & 1.74 & 1.51 & 1.50 \\
\hline $\begin{array}{l}\text { I want to do everything possible for my heath and } \\
\text { for the health of my baby. }\end{array}$ & .00 & 4.68 & 4.72 \\
\hline My well-being positively affects my baby. & .00 & 4.73 & 4.73 \\
\hline
\end{tabular}

The importance of individual motive for exercising has pregnant women defined on a scale from 1 (unimportant) to 5 (very important). Since we've wanted to establish how motivational structure throughout pregnancy changes, we asked pregnant women about motives in pre-pregnancy, at the end of first trimester and at the end of second trimester of pregnancy. The upper table shows the frequency of choice or the meaning of a certain motive among presented ones for exercising in all three periods of measurement.

Throughout pregnancy, as expected, appeared motives for exercising that are connected to a special state of two-in one body. $81,6 \%$ of asked evaluated as very important their own and the baby's health and $84 \%$ of all asked evaluated as very important their own well-being which positively influences on baby's health. 


\section{CONCLUSION}

A pregnant woman puts off a concern about her future because of being preoccupied with present events and near future. Winnicott (Praper, 1995) talks about primary maternal preoccupation, which does not necessary leads to absolute withdrawal from her everyday needs and needs of the others. We can look at that not just as a product of physical part of pregnancy but also as a phase of changes their own old habits which are now focused into an interest for the future concerning the baby. That's why it is expected that new motives will join to the old ones and all together are now focused on mother's well-being, her good health and positive influence on a developing baby.

Our results showed invigoration of motives connected to health and well-being and by development of pregnancy they were more and more focused on a baby. The stronger the motives for exercising, the greater is probability for a pregnant woman to satisfy her own needs and desires in a frame of a healthy life style.

\section{REFERENCE:}

Brown, W. (2002). The benefits of physical activity during pregnancy. I Sci Med Sport, 5(1), pp. 37-45.

Bung, P. (1999). Pregnancy and sport [Schwangerschaft und Sport. In German.]. Gynecology, 32, pp. 386-392.

Clapp, J.F.III. \& Capeless, E.L. (1991). The VO2 max of recreational athletes before and after pregnancy. Med Sci Sport Exercise, 23, pp. 1128-1133.

Černohorski, B. (2001). Motivation and values in top level sport. [Motivacija in vrednote $\mathrm{v}$ vrhunskem športu. In Slovenian.]. (Unpublished master's thesis, University Ljubljana). Ljubljana: Univerza v Ljubljani, Fakulteta za šport.

Gamberger, Ž., Videmšek, M., \& Karpljuk, D. (2005). Pelvic bottom muscle training. [Trening mišic medeničnega dna. In Slovenian.]. Sport, 53(4), pp. 29-32.

Klun, H. (1992). Pregnancy and childbirth. [Nosečnost in porod. In Slovenian.]. Ljubljana: Državna založba Slovenije.

Lochmulller, E.M. \& Friese, K. (2004). Pregnancy and sport [Schwangerschaft und Sport. In German.]. Gynecology, 37, pp. 459466.

Pivarnik, J.M., Ayres, N.A. \& Mauer, M.B., et al. (1993). Effects of maternal aerobic fitness on cardiorespiratory responses to exercise. Med Sci Sport Exerc, 25, pp. 993-998.

Wang, T., \& Apgar, B. (1998). Exercise During Pregnancy. American Family Physician 57(8), pp. 1846-1860.

Završnik, J., Pišot, R., Zurc, J., Žerjal, I.(2004). Physical / sporting activity for health: an interim report on the results of research work on the project within the targeted research program (CRP). [Gibalno/športna aktivnost za zdravje : vmesno poročilo o rezultatih opravljenega raziskovalnega dela na projektu $\mathrm{v}$ okviru ciljnega raziskovalnega programa (CRP). In Slovenian.]. "Konkurenćnost Slovenije 2001-2006". Koper: Univerza na Primorskem, Znanstvenoraziskovalno središče.

Received: October, $1^{\text {st }} 2010$ Accepted: December, $15^{\text {th }} 2010$

Correspodence to: Anja Podlesnik Fetih, PhD Krumperška 15 1230 Domžale Slovenia Phone: +38641255088 E-mail: anjapodlesnik@yahoo.com 


\title{
TRUDNOĆA - STANJE PROMJENA I U PROSTORU MOTIVACIJE ZA BAVLJENJE SPORTOM
}

\author{
Podlesnik Fetih Anja ${ }^{1}$ \\ ${ }^{1}$ Osnovna škola Rakek, Domžale, Slovenija
}

$\mathrm{U}$ radu su prikazani rezultati ankete 163 trudnice prije, na kraju prvog i na kraju drugog tromesečja trudnoće. Anketna pitanja su bila iz motivacije za bavljenje sportskim aktivnostima. Upitnik je sadržavao 23 ajtema iz prostora motivacije prije trudnoće i 25 ajtema u trudnoći. Ispitanice su se opredjeljivale o motivaciji za sportskim aktivnostima na petostepenoj skali

Motivacija za redovnim bavljenjem sportom proizilazi iz činjenice da su ustanovljeni brojni pozitivni efekati vježbanja tokom trudnoće. Sportske aktivnosti pozitivno djeluju na zdravlje trudnice, razvoj fetusa i pripremu za porođaj. Vježbanje takođe pomaže da se prevaziđu neki lakši problemi tokom trudnoće, kao što su opstipacija, umor, mučnina i vomitus, učestalo mokrenje, pospanost i bolovi u donjem dijelu stomaka. Sport i fizičke aktivnosti imaju pozitivan uticaj na psihološko stanje, jačaju kardiovaskularni sistem, pripremaju karličnu muskulaturu za porođaj, pomažu u održavanju tjelesne težine i sprečavaju bolove u krstima i drugim zglobovima. Vježbanjem tokom trudnoće muskulatura karlice postaje snažnija i izdržljivija. Na taj način trudnica aktivno učestvuje u porođaju, što dovodi do bržeg i lakšeg poroda.

Analizirana je učestalost pojave svih motiva u sva tri perioda i određeni su motivi koji su od presudng značaja da se trudnice uključe u sportske aktivnosti prije i u toku trudnoće. Kako bi mogli utvrditi okvire motivacione efikasnosti potrebno je ustanoviti šta trudnice posredno i neposredno motiviše. $U$ osnovi svake motavice je zadati cilj. Cilj je lako odrediti ako se zna čemu ispitanica teži. Ciljevi vježbanja, koje trudnica postavlja, se razlikuju od njenih ciljeva prije trudnoće. Za razliku od vježbanja prije trudnoće, u kome se akcenat daje na oblikovanje mišića, razvoj motoričkih sposobnosti, razvijanje izdržljivosti i samo izvođenje vježbe, u trudnoći su vježbe jednostavnije $\mathrm{i}$ izvode se sa manjim intenzitetom. Trudnice prije svega trebaju da upražnjavaju vježbe disanja ali pri tome ne smiju da pretjeruju. Tokom trudnoće ne bi se trebale koristiti nove (nepoznate) sportske aktivnosti, kako ne bi došlo do povreda. Vježbanje treba porovoditi u takvom obimu i intenzitetu koje omogućava trudnicama opuštanje i dobro raspoloženje.

Motivacione strukture su relativno trajne strukture kognitivno-konativnog prostora i počinju se razvijati u ranom djetinjstvu. Zato se može očekivati da će se odabrani motivi pojavljivati u svim periodima mjerenja. Utvrđeno je da bi trudnice trebalo prosvećivati o značaju i uticaju sporta i fizičke aktivnosti na zdravlje i blagostanje djeteta. Motivi unutar motivacione strukture se mogu mijenati pod određenim okolnostima. Rezultati govore da se u trudnoći najčešće javljaju motivi radi zdravlja i pozitivnog uticaja na zaštitu nerođenog djeteta.

Kada govorimo o motivacijskim tokovima mislimo na one koje svaka ispitanica, bez obzira da li je ona toga svjesna ili ne, da li su joj poznati ili ne, vidi kao korisne u svom životu. Od stepena uspješnosti njihovog djelovanja zavisi stepen prilagođavanja životnim okolnostima. Dominacija jednog ili više motiva nad drugima je posljedica različitih životnih situacija i individualnog iskustva. Trudnoća kao stanje potpune fiziološke i psihološke promjene takođe djeluje i na promjenu motiva ispitanica.

Provedeno istraživanje govori upravo o tome. U vremenu prije trudnoće najšeće su se pojavljivali motivi: želim biti tjelesno sposobna, želim sačuvati svoje zdravlje, želim poboljšati svoje zdravlje i želim biti dobar uzor svojoj djeci. Manje izraženi motivi su: takmičenje, poslovni razlozi $i$ naklonst in- 
struktora. Od trenutka kada žena shvati da je trudna počinje da se prilagođava novom stanju i pored starih pojavljuju se i novi motivi koji ostaju relativno stabilni tokom trudnoće. Pored već pomenutih starih motiva pojavljuju se dva nova motiva koja smo nazvali zdravlje nerođenog djeteta i pozitivan uticaj majčinog dobrog raspoloženja na dijete. Motivi koji se prije trudnoće javljaju sa manjom učestalosti ostaju takvi i tokom trudnoće.

U trudnoće su se pojavili motivi za sportske aktivnosti koji su vezani za posebno stanje dvije osobe u jednom tijelu. Da su motivi značajni za zadravlje trudnice i djeteta izjasnilo se $81,6 \%$ ispitaniuca, a $84,0 \%$ smatra da dobro osjećanje majke ima pozitivan uticaj na zdravlje djeteta.

Trudnica stavlja u drugi plan svoja razmišljanje o budućnosti pošto je preokupirana brigom za trenutne i bliske događaje. Misli se, prije svega, o primarnoj materinjskoj preokupaciji. Ali to je ne odvlači od njenih ustaljenih potreba i potreba koje od nje očekuju drugi. $\mathrm{Na}$ to možemo gledati ne kao posljedicu samoga stanja trudnoće, već takođe i kao na promjenu njenih starih navika koje su sada usmjerene na buduću brigu o djetetu. Zato je za očekivati da se već na formiranu motivacijsku strukturu, u tom period, formiraju novi motivi koji su usmjerni prema dobrom zdravlju majke, njenom dobrom psihičkom stanju i pozitivnom uticaju na razvoj djeteta.

Rezultati su pokazali da prevladavaju motivi koji su vezani za zdravlje i blagostanje majke, a napredovanjem trudnoće motivi su bili sve više usmjerni prema djetetu. Što su motivi za sportsku aktivnost izraženiji time je veća vjerovatnoća da će trudnica svoje želje i potrebe zadovoljiti u okviru zdravog načina života. Zato je važnost da je svaka trudnica svjesna značaja sportske aktivnosti i zdravog načina života kako bi time dobila višestruke pozitvne efkete, kako za seba tako i za razvoj njenog djetata.

Ključne riječi: motivaciona struktura, sportske aktivnosti, trudnoća. 